\title{
The Informative and Referential Pragmatic Function in Parent-Child Interactions in Jordan*
}

\author{
Omar Alkhateeb, Mahmud Wardat \\ Yarmouk University, Irbid, Jordan
}

\begin{abstract}
The present paper investigates the informative and referential pragmatic function parent-child interactions in Irbid City, Jordan. A sample of 100 school children from different areas of Irbid was chosen randomly from Irbid governorate in North Jordan. It consisted of grade 5 pupils who are 11 years old. Half of the samples were males, whereas the second half were females. A questionnaire of five items was given to the sample to measure the expressive and emotive pragmatic function. The results indicated that parent-child interactions in Jordan exhibit this pragmatic function. The results also showed that parents' interactions affect children's personality and behavior positively through applying certain tactics and styles.
\end{abstract}

Keywords: parent-child interactions, the informative and referential pragmatic function, parents, children, behavior, personality

\section{Introduction}

The informative and referential function, as defined by Jakobson (1960, pp. 353-357) and discussed by other linguists such as Newmark (1988, pp. 39-44), means informing people about topics that a person feels or knows, so the speaker refers to certain information that he knows. It is a significant function because via expressing feelings, the speaker gives information which is important for the addressee to bear in mind.

\section{E.g., The earth is round}

In this example, the speaker is telling the listener information that he already knows, so he refers to his previous knowledge to tell someone something.

Grimshaw (2001, p. 750) stated that there is a close relationship between language represented by discourse, talk, and conversation, on the one hand, and society represented by social organization, social structure, and social interactions, on the other. This means that society is responsible for language use. One of the examples that might be helpful here is the word "Queen" which is used originally for the wife, but nowadays restricted to the king's wife (Geeraerts, 2006, p. 27).

Parents are, nonetheless, responsible for their children, because children are attached to their parents. They learn much through this attachment. Thus, language acquisition and language are affected directly by parents. Since discourse is the main channel of communication development, it plays a great role in affecting parent-child interactions.

\footnotetext{
${ }^{*}$ Acknowledgements: This paper further develops an idea presented in the M.A. thesis written by the first author and supervised by the second author.

Omar Alkhateeb, researcher and translator, M.A., English Department, Yarmouk University, Irbid, Jordan.

Mahmud Wardat, professor of linguistics, Ph.D., English Department, Yarmouk University, Irbid, Jordan.
} 
Wardat and Alkhateeb (2016) studied the emotive and expressive function of parent-child interactions in the Jordanian society. The results showed that parent-child interactions in the Jordanian society exhibit the emotive and expressive socio-pragmatic function.

Rosli (2014) investigated the relationships between the styles practiced by parents and the emotional and behavioral problems they cause. The study is limited to Muslim American children. The results showed no statistically significant differences in emotional and behavioral problems between the various Muslim parenting groups. Parents' consistent behavior had no effect on their children's emotional and behavioral difficulties. In the sample, Muslim fathers commonly used the authoritative parenting style, while the Muslim mothers commonly used the authoritarian parenting style.

The paper and the current one are concerned with children's behavior. The sample of the paper is parents, but in the current one the sample is children. Moreover, the paper is concerned with Muslims in America, whereas the current one is concerned with children in Jordan, so it does not pay attention to religion.

Migdady and AL Migdadi (2014) studied the parents' different styles of interaction and their effects on their children's behavior in the classroom. The sample consisted of 50 second grade children, which means that they deal with subjects aged seven from both genders. The results of the study showed that there was an effect of parents' interaction styles on the children's behavior in the classroom. The results also manifested that females were different from males at the level of adaptation affected by the parents' interaction style. The study was limited to teacher-child interactions at school, but the current study deals with children's interactions with friends and relatives.

Goldberg (2014) assumed that positive reinforcement is helpful to the personality of children, whereas criticism prevents them from growth and development. He stated 15 pillars of parenting that are tools for guidance and support. He divided those pillars into four preparations, five attitudes, and six techniques which work side by side to develop children's personalities. The study is concerned with how parents affect their children psychologically. It gives useful examples but ignores the social effects on children's language and interactions. Furthermore, there is no defined population, but it only provides general guidelines for parents. The techniques changing the environment, using the Sandwich method for supervision, being a part of the solution, reacting with humor when appropriate, touching, and missing a reward, are tested in the current study to see whether they are applicable in the Jordanian setting or not. Moreover, the study has no population; it is a theoretical study.

Liebeskind et al. (2014) assumed that children who have strong language skills are better than those who have weaker skills. They are concerned with the effect of media and parents on the production of children's language in the American society. The study indicated that the effect of media on the children's language came through the mediation of parents to guide their children. This finding guided parents to give importance to their relationship with their children to develop their mental abilities and to employ this development in their world which is the school.

Their research is limited to the effect of media and parents on the development of children's language at school, but our study is concerned with the whole child's world, friends, and relatives, in addition to media and parents.

Houltberg (2010) was concerned with the youth understanding of the family relations and systems on the one side, and the parents' anger in high risk communities on the other. He examined the youth understanding of their parents' stress which might affect their relationship with their parents. Cohesion and adaptability were 
tested and the normal parents' behaviors (support and supervision) were tested too. Youth understanding of family cohesion and adaptability was related to the parents' nervousness through a positive relationship with parental support. Family cohesion was indirectly connected to having violence through a positive relation to supervision, but adaptability was indirectly related through a negative relationship with supervision.

This study is related to the current one, because both are concerned with social behavior. Nevertheless, the study is concerned with youth and the current one deals with children who are still younger than the population of the study and they are still young to understand the systems of family.

Dwairy et al. (2006) carried out a survey study, investigating the authoritarian style in eight Arab societies. The sample consisted of 2,893 Arab adolescents. Results showed that all parenting styles change from one to another Arab society. Analysis uncovered three combined parenting patterns: inconsistent (permissive and authoritarian), controlling (authoritarian and authoritative), and flexible (authoritative and permissive). On the parents' side, the mean score of the feel of obligation (authoritarian style) was higher among males, whereas the mean score of the feel of power (authoritative style) was higher among females. On the children's side, the eldest adolescents reported higher level permissive parenting than other adolescents. Parents' education, civilization, and economic level had minor effects on both parents' and children's styles.

This research and the current one are both concerned with children. This research is concerned with the parents' authoritarian style in the family, but it pays no attention to the other styles like giving pieces of advice and developing the children's good behavioral interactions which the current study will shed the light on. Moreover, the sample covered eight Arab countries, which have various values and traditions, which might affect the findings, but the sample of the current study covers children in Jordan only.

Hassall, Rose, and McDonald (2005) were concerned with intellectual disabilities. They shed light on the associations between parental cognitive characteristics, child disabilities, family supportive styles, and parents' stress on their children. The study looked upon two of the parents' cognitions: parenting self-esteem (including efficacy and satisfaction) and parental point of control. The sample consisted of 46 mothers having children with intellectual disabilities. The results showed that parent' stress is related to parental point of control, parents' satisfaction, and child behavior disabilities.

The study and the current one are concerned with children's behavior. Nevertheless, the study is concerned with children with intellectual disabilities, but the current one is concerned with normal children. The sample in the study consisted of the mothers (parents), but the sample in the current one consisted of children.

Laible (2004) stressed the importance of the daily discourse between mothers and their children. The study examines the effect of the daily parents' discourse on their children and the way they shape their thoughts in order to be active in their society. She also studied the attachment security, which means the parents' taking care of their child's needs and linguistic sensitivity. The data analysis reveals that the parents' effect on their children's world does not only come from the content of their discourse, but also from the daily discourse which takes place between parents and their children. The sample consisted of 51 preschool children and their mothers who were videotaped reading a story and discussing the child's previous behavior. The results showed that both aspects of mother-child discourse, the style and content of discourse were related to attachment, temperament, and the child's development in the society.

Laible's study relied on Vygotsky's (1978, pp. 79-91) work. According to Vygotsky, language does not only provide the child with a new social context to participate in, but also provides the means for organizing 
and shaping his thought. Laible found that owing to parents' discourse, a child learns social, emotional, and moral experiences. She also gave good information about the effects of the daily discourse on the social mentality and personality of the child; caregivers teach their children what types of behavior are accepted by the society and what types are not. The current research will be concerned with pragmatic issues in addition to social issues.

The literature review shows that there are many studies on parent-child language acquisition which affects children's behavior and personality at school age (e.g., Laible, 2004; Dwairy et al., 2006; Migdadi \& Al Migdadi, 2014; Goldberg, 2014; Liebeskind et al., 2014). It is clear that no study has so far looked upon parent-child interactions in Jordan. While most of the previous studies deal with children's behavior at school, the current study is concerned with the home effects on pupils' behavior and personality.

Finally, there is no study that handles the informative and referential pragmatic function of parent-child interactions from children's point of view. Thus, there is a pressing need to investigate parent-child interactions in the Jordanian family. The current study will fill a gap in the related literature.

The ultimate goal of the present study is, therefore, to examine the informative and referential pragmatic function of the parent-child interactions and to determine the degree of the effects of parents on children's behavior from pupils' point of view. The study will, thus, try to answer the following question:

How are children's behavior and personality affected by their parents' discourse in the Jordanian family?

\section{Methods}

\section{Population}

The population is all fifth graders in Irbid schools, Jordan. The population of Irbid governorate is about 1,137,100 Jordanian citizens. Males are about 582,400, whereas females are about 554,700 as estimated by the Department of Statistics (2012). The whole population speaks the rural variety of Jordanian Arabic (JA).

\section{Sample}

A sample of 100 children from different areas of Irbid was chosen randomly from primary schools in Irbid governorate in North Jordan. It consisted of pupils at grade five who are 11 years old. Half of them were males, whereas the second half were females. The sample covered children who were met only at schools.

\section{Data Collection}

In this study, face-to-face visits were made to the children at Irbid governorate schools before the end of the second school semester 2014/2015. During the school classes, a five-item questionnaire (see Appendices 1 and 2) was distributed to the subjects who were met for the first time. One researcher explained the purpose of the study and the questionnaire. After the subjects' agreement, they were given 10 minutes to answer all the questionnaire items by marking a tick in the right square in the first part and writing their viewpoints of their fathers' and mothers' characteristics in the second part. The questionnaire concentrated on the relationship between parents and their children, and the effects of this relationship on the discourse and behavior of the children at home and in their society. The questionnaire was divided into two parts:

(1) The first part was intended to provide the researchers with information about the nature of the relationship between parents and their children and how this relationship affects children's behavior at home and in the outside world. 
(2) The second part was supposed to give the researchers indications of the good and bad conducts or qualities which children find in their parents, but the respondents did not answer this part. Thus, it is disregarded in data analysis.

The questionnaire had two parallel forms; one was special for the relationship between a child and his mother and the other for the relationship between the child and his father. Both forms were given to male and female children. The form of the questionnaire in the current study followed the questionnaire used by Titze et al. (2014, pp. 917-933). Their questionnaire was adapted to serve the purpose of the current study. Since the subjects of the sample are Arab children whose English proficiency is not that much satisfactory, the questions were translated into Arabic and then they were distributed to them.

Finally, the study deals with normal children, so it excludes other children who have medical problems such as aphasics, deafness, or blindness. Also, the paper is limited to eleven-year-old children, so it does not deal with adults or infants.

\section{Reliability and Validity}

Reliability. Since children are the subjects of the study who are affected by parents' discourse, a test-retest is the method followed to establish reliability of the tool of this study. The test group consisted of a small sample (20 pupils) randomly selected from the population and excluded from the main sample. Then, the questionnaire was given to the main group during the first week of May 2015. To show the effects of parents on their children, a statistical analysis was carried out for the collected data. As a sequence, the same questionnaire was given to the same group under the same conditions during the last week of May 2015.

The results of the test show that Cronbach's Alpha for the Father's sample is 0.884 and for the Mother's sample it is 0.845 . The previous results are considered to be of high value and a piece of evidence of consistency in the five items that were used to measure the father/mother-son/daughter relations. See Table (1).

Table 1

Cronbach's Alpha Test

\begin{tabular}{lll}
\hline Reliability statistics & & \\
\hline Sample & Cronbach's alpha & No. of items \\
\hline Fathers sample & 0.884 & 5 \\
Mothers sample & 0.845 & 5 \\
\hline
\end{tabular}

Content-validity. The content of the questionnaire was given to a jury of three linguists from the English Department at Yarmouk University. They were kindly requested to judge the content of the questionnaire, stating whether the research instrument is valid for this study or not. The jury stated that the questionnaire (see Appendices $1 \& 2$ ) is valid in the sense that it can measure what it is supposed to measure.

\section{Data Analysis}

The data were analyzed to determine the effects of the informative and referential socio-pragmatic function of the parent-child interactions. An interpretation of such interactions in each question was carried out according to what it functioned in the parent-child relationship. The related literature showed the styles of discourse used by parents in their relationship with their children; ignoring children, reinforcing children, and motivating children are styles that can lead to the informative and referential pragmatic function which is the scope of data analysis. 
The questionnaire had five items directed to the school children whose responses were computed as follows:

Never was given 1 point, rarely 2 points, sometimes 3 points, often 4 points, and Always 5 points. Then, averages, percentages, and standard deviation were also computed.

In the discussion, tables summarize respondents' answers including the answers of five choices "never", "rarely", "sometimes", "often", and "always". The researchers grouped answers into three groups; while the negative group includes the average of the answers "never" and "rarely", the positive group includes the average of the answers "often" and "always". The third group consisted of the "sometimes" respondents.

After collecting data, the researchers analyzed them qualitatively and quantitatively according to the following equations:

(1) $\overline{\mathrm{x}} \leq 2.5=$ negative response;

(2) $\bar{x}>2.5$ and $<3.5=$ sometimes response;

(3) $\bar{x} \geq 3.5=$ positive response.

Moreover, the T-test has been carried out to show whether there are statistically significant differences between the father's questionnaire and the mother's for each question.

Finally, the second part of the questionnaire was, as mentioned earlier, excluded from the analysis since the respondents did not answer it.

\section{Significance of the Study}

The significance of the study stems from exploring the informative and referential pragmatic function of the parent-child discourse in the Jordanian society. Moreover, the study will give information regarding the pragmatic interactions that might show the level of congruence of the relationship between the Jordanian Family. Through discourse situations such as politeness, respect, and other interactions, the study will shed light on the content and style of discourse from a pragmatic point of view. The study also focuses on the family discourse as a starting point which will affect children's behavior and personality in the whole society.

\section{Results and Discussion}

The researchers try to investigate whether children at home have the opportunity to give information they already know and express themselves, on the one hand, and if children get the right to decide upon something within their families, on the other hand. For the sake of this investigation, questions are devised to measure whether children are asked about their opinions, helped in their homework, receiving an intensive care, asked for advice, and able to decide upon something.

\section{The Effect of the Last Word}

In interactions, if correspondents decide on something, the decision is raised by one of them. In the family, parents and children should participate in communicative events; parents are responsible for having the last word; yet, they can give the opportunity to their children to decide on something as a reinforcement style of children's personality. This question has been directed to the respondents to confirm responses to other questions (asking children for their opinion, helping children with homework, taking care of children, and asking for advice) which are parts of the informative and referential function. The respondents' answers are shown in Table (2): 
Table 2

The Effect of the Last Word

\begin{tabular}{|c|c|c|c|c|c|c|c|}
\hline \multirow{3}{*}{$\begin{array}{l}\text { Q1: My father/mother } \\
\text { has the last word in any } \\
\text { chat. }\end{array}$} & \multicolumn{4}{|c|}{ Sample } & \multirow{2}{*}{\multicolumn{3}{|c|}{ T-test for equality of means }} \\
\hline & \multicolumn{2}{|c|}{ Father's sample } & \multicolumn{2}{|c|}{ Mother's sample } & & & \\
\hline & Frequency & Percentage & Frequency & Percentage & $\mathrm{T}$ & d.f & Sig. (2-tailed) \\
\hline Never & 6 & $12.0 \%$ & 4 & $8.0 \%$ & \multirow{7}{*}{-1.162} & \multirow{7}{*}{98} & \multirow{7}{*}{.248} \\
\hline Rarely & 2 & $4.0 \%$ & 8 & $16.0 \%$ & & & \\
\hline Sometimes & 3 & $6.0 \%$ & 16 & $32.0 \%$ & & & \\
\hline Often & 8 & $16.0 \%$ & 8 & $16.0 \%$ & & & \\
\hline Always & 31 & $62.0 \%$ & 14 & $28.0 \%$ & & & \\
\hline \multirow[t]{2}{*}{ Total } & 50 & $100.0 \%$ & 50 & $100.0 \%$ & & & \\
\hline & Mean & 4.12 & Mean & 3.40 & & & \\
\hline
\end{tabular}

When asked if their mother has the last word in any chat, $24 \%$ of children said "never" and "rarely", but $76 \%$ said "sometimes", "often", and "always", whereas for fathers, the majority of children (84\%) responded that their father always has the last word in any chat. The T-test shows that there is no statistically significant difference at $\alpha=0.05$ level $(\mathrm{p}>0.05)$ between respondents' answers of Fathers' and Mothers' questionnaires.

Parents' last word in any interaction has advantages and disadvantages. It is useful to keep the first authority (parents) at the high level of command and control in decision making related to children's respecting of other people, being polite with their siblings, accepting the other opinion, being compliant to their parents, and gaining their parents' experience of life. On the other side, sometimes the role of parents is to give their children the green light to talk freely when the child, for example, wants to buy a certain shirt or wants to help his parents do something; such cases will develop the child's self-confidence and maximize his ability to face hard events or times. In this way, parents will be able to guide their children and keep them in the right track by giving them their experience and wisdom to help determine what is right and what is wrong.

Dwairy et al. (2006, p. 12), in their study of the authoritarian style in Arab societies, showed that fathers and their sons have the feel of the authoritarian style of obligation. The results of this study support Dwairy et al.'s results of the fathers' authoritarian one of communication between fathers and their sons in Arab societies. The current study adds another result concerning the mothers' style which is also an authoritarian one with their children. The findings of this research might be related to the fact that parents try to keep controlling their children at the age 6-11 because children at this age are not aware of what they have to decide upon. Further, in so doing, parents encourage children to think profoundly and to give their opinion of their parents' behavior.

\section{The Effect of Asking for Children's Advice}

Parents are well experienced but do not know everything in life; thus, they need assessment from others. It is the house where they find themselves talk freely with each other and can freely ask for advice. Table 3 shows the respondents' answers regarding the effect of parents' asking for advice. 
Table 3

The Effect of Asking for Children's Advice

\begin{tabular}{|c|c|c|c|c|c|c|c|}
\hline \multirow{3}{*}{$\begin{array}{l}\text { Q2: My father/mother } \\
\text { asks for advice when he } \\
\text { needs it. }\end{array}$} & \multicolumn{4}{|c|}{ Sample } & \multirow{2}{*}{\multicolumn{3}{|c|}{ T-test for equality of means }} \\
\hline & \multicolumn{2}{|c|}{ Father's sample } & \multicolumn{2}{|c|}{ Mother's sample } & & & \\
\hline & Frequency & Percentage & Frequency & Percentage & $\mathrm{T}$ & d.f & Sig. (2-tailed) \\
\hline Never & 7 & $14.0 \%$ & 2 & $4.0 \%$ & \multirow{7}{*}{-.219} & \multirow{7}{*}{98} & \multirow{7}{*}{.827} \\
\hline Rarely & 10 & $20.0 \%$ & 17 & $34.0 \%$ & & & \\
\hline Sometimes & 8 & $16.0 \%$ & 12 & $24.0 \%$ & & & \\
\hline Often & 11 & $22.0 \%$ & 5 & $10.0 \%$ & & & \\
\hline Always & 14 & $28.0 \%$ & 14 & $28.0 \%$ & & & \\
\hline \multirow[t]{2}{*}{ Total } & 50 & $100.0 \%$ & 50 & $100.0 \%$ & & & \\
\hline & Mean & 3.30 & Mean & 3.24 & & & \\
\hline
\end{tabular}

The sample manifested that both parents ask for advice when needed. For father's sample, $66 \%$ of the respondents answered "sometimes", "often", and "always". Another positive result was shown in the mother's sample; $62 \%$ answered "sometimes", "often", and "always". The T-test shows that there is no significant difference at $\alpha=0.05$ level ( $p>0.05$ ) between respondents' answers of Fathers' and Mothers' questionnaires. The results are considered as positive evidence that parents are willing to ask for and accept advice.

Zolten and Long $(2006$, p. 4) argued that parents take time and effort to strengthen their relationship and communication skills with their children. Asking children for advice will upgrade the children's ability of expressing themselves and should also give them self-confidence later on when they go out and share the society with their opinions. Establishing a good relationship and a good communication can be reached through talking with children as much as parents can. Parents should bear in mind that communication is not just giving directives, but it is a two-way style; it is a kind of listening to children, on the one hand, and discussing various issues with children, on the other. Listening to children's opinion is as important as talking to them and sometimes more important than talking because listening to children's opinion enables children to take their time to think of and express their ideas, which will give them the opportunity to feel that they are effective in the society.

Urging children to give their advice comes from asking children open-ended questions: wh-questions which contain the words "what", "where", "whom", "why", "how", and the like. Such questions are useful in making children think in an open mind. On the contrary, yes or no questions will limit children and prevent them from expressing themselves. Finally, parents should overcome distractions and obstacles and give full attention to children when they start talking. These wh- questions give children the opportunity to express their ideas especially when parents ask them about their opinions of doing or not doing something.

In the related literature, Goldberg (2014, p. 12) argued that reinforcement affects children's language and personality. Asking children for pieces of advice can be a good strategy to teach children how to think, express themselves, and give their viewpoints. The results of this study indicate that parents allow children to give their reaction through asking for advice. Parents' asking for advice might be attributed to the parents' high literacy and self-confidence. It could also be attributed to parents' desire to encourage children to take part in communicative activities without hesitation.

\section{The Effect of Helping Children with Homework}

The investigation showed that a low level of attention is paid to homework. The results are shown in the following table: 
Table 4

The Effect of Helping Children With Homework

\begin{tabular}{|c|c|c|c|c|c|c|c|}
\hline \multirow{3}{*}{$\begin{array}{l}\text { Q3: My father/mother } \\
\text { helps me with my } \\
\text { homework }\end{array}$} & \multicolumn{4}{|c|}{ Sample } & \multirow{2}{*}{\multicolumn{3}{|c|}{ T-test for equality of means }} \\
\hline & \multicolumn{2}{|c|}{ Father's sample } & \multicolumn{2}{|c|}{ Mother's sample } & & & \\
\hline & Frequency & Percentage & Frequency & Percentage & $\mathrm{t}$ & d.f & Sig. (2-tailed) \\
\hline Never & 11 & $22.0 \%$ & 7 & $14.0 \%$ & & & \\
\hline Rarely & 16 & $32.0 \%$ & 17 & $34.0 \%$ & & & \\
\hline Sometimes & 12 & $24.0 \%$ & 14 & $28.0 \%$ & -2.013 & 98 & .047 \\
\hline Often & 7 & $14.0 \%$ & 6 & $12.0 \%$ & & & \\
\hline Always & 4 & $8.0 \%$ & 6 & $12.0 \%$ & & & \\
\hline \multirow[t]{2}{*}{ Total } & 50 & $100.0 \%$ & 50 & $100.0 \%$ & & & \\
\hline & Mean & 2.54 & Mean & 2.74 & & & \\
\hline
\end{tabular}

When asked if his or her mother helps with homework, $48 \%$ of children said "never" and "rarely", $52 \%$ said "sometimes", "often", and "always". However, when asked the same question of his or her father, $54 \%$ of children said "never" and "rarely", whereas $46 \%$ said "sometimes", "often", and "always". The T-test shows that there is a statistically significant difference in favor of mothers at $\alpha=0.05$ level $(p<0.05)$ between respondents' answers of Fathers' and Mothers' questionnaires.

The results of this research show that the sample was divided into two parts which are almost balanced; almost half of the sample answered negatively and almost half answered positively. The previous results give a piece of evidence that parents in Jordan do not pay necessary attention to their children's homework. The low level of parents' helping their children with their homework might be attributed to the parents' shortage of time, dependency on private teachers, and parents' lack of knowledge of the subject matter or lessons that children are taking, and parents' carelessness of the significance of homework and its role in advancing their children's learning skills.

\section{The Effect of Taking Care of Children}

The findings of Question (4) are shown in Table (5):

Table 5

The Effect of Taking Care of Children

\begin{tabular}{|c|c|c|c|c|c|c|}
\hline \multirow{3}{*}{$\begin{array}{l}\text { Q4: My father/mother } \\
\text { takes care of me }\end{array}$} & \multicolumn{4}{|c|}{ Sample } & \multirow{2}{*}{\multicolumn{2}{|c|}{ T-test for equality of means }} \\
\hline & \multicolumn{2}{|c|}{ Father's sample } & \multicolumn{2}{|c|}{ Mother's sample } & & \\
\hline & Frequency & Percentage & Frequency & Percentage & d.f & Sig. (2-tailed) \\
\hline Never & 0 & $0.0 \%$ & 2 & $4.0 \%$ & \multirow{7}{*}{-3.069} & \multirow{7}{*}{.003} \\
\hline Rarely & 3 & $6.0 \%$ & 4 & $8.0 \%$ & & \\
\hline Sometimes & 6 & $12.0 \%$ & 0 & $0.0 \%$ & & \\
\hline Often & 2 & $4.0 \%$ & 1 & $2.0 \%$ & & \\
\hline Always & 39 & $78.0 \%$ & 43 & $86.0 \%$ & & \\
\hline \multirow[t]{2}{*}{ Total } & 50 & $100.0 \%$ & 50 & $100.0 \%$ & & \\
\hline & Mean & 4.54 & Mean & 4.58 & & \\
\hline
\end{tabular}

When asked if his or her mother takes care of him or her, the overwhelming majority of children $(86 \%)$ said "always"; the majority of children (78\%) also felt their father always took care of them. This positive result demonstrates that parents are responsive and try their best to take care of their children. The T-test shows that there is a statistically significant difference at $\alpha=0.05$ level $(\mathrm{p}<0.05)$ between respondents' answers of 
Fathers' and Mothers' questionnaires. The result is in favor of mothers (where children think mothers take care of them more than their mathers do).

Zolten and Long (2006, pp. 2-4) gave some pieces of advice for responsive parents' talk to their children. One piece of advice is to simplify the level of communication to establish a useful communication. According to Zolten and Long, word-choice is important for parents; using simple words can be easily understood by children, so that children can understand the last intent of their parents. When children feel that they do not understand what parents are saying, they will not be encouraged to communicate with their parents and they probably feel hesitant to communicate with other people outside the house.

Another piece of advice is to keep accepting, loving, and taking care of children. These emotional traits will affect the psychology of children; children will feel that they are close to their parents and will be motivated to share in any chat. Physically, parents should use some tactics that can be useful like hugging, being calm (not shouting), facing children when they talk, and sharing children their leisure time without neglecting their feelings.

Laible (2004, p. 979) argued that parents should give top priority to their children and remove everything that can interrupt their interaction. When children express a desire to talk, parents should give them their full attention. Opening communication between parents and children should lead to good parent-child relationships. The results of the current study concerning parents' taking care of children support Laible's results. Although Laible's study is concerned with infants and the current research is concerned with children, both studies show that taking care of children leads to children's good interactions. The positive results of the current research might be attributed to the responsibility of parents for offering the needs of their children. The results also show a fathers' lower interest of taking care of their children than the mothers' interest, which might be attributed to the mothers' close relations with their children and the mothers' psychology and kindness.

\section{The Effect of Asking for Opinion}

Parents' asking for children's opinion is one of the strategies that affect children's personality. The respondents' answers are shown in the following table.

Table 6

The Effect of Asking for Opinion

\begin{tabular}{|c|c|c|c|c|c|c|c|}
\hline \multirow{3}{*}{$\begin{array}{l}\text { Q5: My father/mother } \\
\text { asks me for my opinion }\end{array}$} & \multicolumn{4}{|c|}{ Sample } & \multirow{2}{*}{\multicolumn{3}{|c|}{ T-test for equality of means }} \\
\hline & \multicolumn{2}{|c|}{ Father's sample } & \multicolumn{2}{|c|}{ Mother's sample } & & & \\
\hline & Frequency & Percentage & Frequency & Percentage & $\mathrm{t}$ & d.f & Sig. (2-tailed) \\
\hline Never & 3 & $6.0 \%$ & 2 & $4.0 \%$ & \multirow{7}{*}{-.882} & \multirow{7}{*}{98} & \multirow{7}{*}{.380} \\
\hline Rarely & 10 & $20.0 \%$ & 3 & $6.0 \%$ & & & \\
\hline Sometimes & 17 & $34.0 \%$ & 19 & $38.0 \%$ & & & \\
\hline Often & 10 & $20.0 \%$ & 13 & $26.0 \%$ & & & \\
\hline Always & 10 & $20.0 \%$ & 13 & $26.0 \%$ & & & \\
\hline \multirow[t]{2}{*}{ Total } & 50 & $100.0 \%$ & 50 & $100.0 \%$ & & & \\
\hline & Mean & 3.28 & Mean & 3.64 & & & \\
\hline
\end{tabular}

The sample answered positively when asked if his or her mother asks for his or her opinion; $90 \%$ of children responded "sometimes", "often", and "always", whereas when asked if their father asks for his or her opinion, $74 \%$ of children responded "sometimes", "often", and "always". The T-test shows that there is no statistically significant difference at $\alpha=0.05$ level $(p>0.05)$ between respondents' answers to Fathers' and 
Mothers' questionnaires. The previous results mean that parents are aware of the importance of asking their children about their opinions.

Parents, the major authority that influences children, have the opportunity to guide children in making decisions. Parents encourage their children to make decisions by considering their opinions. They discuss opinions of their children, clarifying all possible alternatives and giving children the opportunity to evaluate these alternatives and to end up with a decision that might come right from the child himself (Torgeir \& Brennan, 2011, p. 353).

The positive results in this study give importance to children's opinions even if parents do not need these opinions. The tactic of asking children for opinion gives children the chance to express themselves and upgrade their behavioral skills through imitating the styles used by parents. This finding supports Liebeskind et al.'s (2014) results which showed the effect of parents on the development of their children's language skills through the good relationship with their children. The positive results of the effect of parents' asking for children's opinion might be attributed to parents' high flexibility with their children and their attempt to train and develop their critical and analytical thinking and skills. This training should be highlighted and enhanced so that children do not take things for granted.

\section{Summary}

The T-test shows that there is no statistically significant difference at $\alpha=0.05$ level $(p>0.05)$ between respondents' answers of Fathers' and Mothers' questionnaires. The mean of the two father and mother samples shows that the informative and referential function is available in the Jordanian society. The mean of the two samples (father sample $=2.928$ and mothers' $=2.78$ ) means that the function is there. See Table (7).

Table7

The Informative and Referential Function. T-Test

\begin{tabular}{clllll}
\hline The informative and referential function & Mean & Std. deviation & T & df & Sig. (2-tailed) \\
\hline Father & 2.928 & 1.57121 & 1.045 & 498 & .297 \\
Mother & 2.78 & 1.59681 & & & \\
\hline
\end{tabular}

Migdadi and AL Migdadi (2002) pointed out that children's behavior at school is affected by their parents' interactions. The results of the current study support Migdadi and AL Migdadi's findings; the results show that the informative and referential function is available not only at school, but also in the Jordanian family and affects the children's behavior.

\section{Conclusion}

The informative and referential function indicates how children can get and can give information within the family. The effects mentioned above serve to show how parents affect their children through this function. This research showed that the effects or questions are important to develop the personality and communication of children within the family and will positively affect children's communication in the society as well.

In the Jordanian family, although parents take care of their children, give importance to their children's opinion, and ask for advice when needed, parents do not help their children with their homework and parents have the last word in any chat. 


\section{References}

Dwairy, M., Achoui, M., Abouserie, R., Farah, A., Sakhleh, A. A., Fayad, M., \& Khan, K. H. (2006). Parenting styles in Arab societies. Journal of Cross-Cultural Psychology, 3(37), 230-247.

Geeraerts, D. (2006). Theories of lexical semantics. New York: Oxford University Press.

Goldberg, L. (2014). Parent-child interaction. Retrieved from Education.com

Grimshaw, A. (2001). Discourse and sociology: Sociology and discourse. In Deborah Schiffren et al. (Eds.), The handbook of discourse analysis (pp. 750-772). Oxford: Blackwell Publishers Ltd.

Hassall, R., Rose, J., McDonald, J. (2005). Parenting stress in mothers of children with an intellectual disability: The effects of parental cognitions in relation to child characteristics and family support. Journal of Intellectual Disability Research, 49, 405-418.

Houltberg, J. B. (2010). Family system qualities, parenting behaviors, exposureto violence, and emotion regulationin low-income urban youth. USA: Oklahoma State University.

Jakobson, R. (1960). Closing statement: Linguistics and poetics. In T. A. Sebeok (Ed.), Style in language (pp. 350-377). New York, London: The Technology Press of Massachusetts Institute of Technology and John Wiley \& Sons, Inc.

Laible, D. (2004). Mother-child discourse in two contexts: Links with child temperament, attachment security, and socio-emotional competence. Developmental Psychology, 40, 979-992.

Liebeskind, K., Piotrowski, T. J., Lapierre, A. M., \& Linebarger, L. D. (2014). The home literacy environment: Exploring how media and parent-child interactions are associated with children's language protection. Journal of Early Childhood Literacy, 4(14), 482-509.

Migdady, Y., \& AL Migdadi, M. (2014). Parents' interaction styles and their relationship with the level of adaptation of children in classroom. Dirasat, Educational Sciences, the University of Jordan, Amman, Jordan, 41(1), 305-314.

National Council for Family Affairs. (2010). Annual report. Retrieved from www.ncfa.org.jo

Newmark, P. (1988). A textbook of translation. New York: Prentice-Hall International.

Rosli, N. A. (2014). Effect of parenting styles on children's emotional and behavioral problems among different ethnicities of Muslim children in the U.S. (Paper 376). Retrieved from http://epublications.marquette.edu/dissertations_mu/376

Titze, K., Schenck, S., Logoz-Zulauf, M., \& Lehmkuhl, U. (2014). Assessing the quality of the parent child relationship: Validity and reliability of the child-parent relationship test (ChiP-C). Journal of Child and Family Studies, 23(5), 917-933.

Torgeir, W., \& Brennan, L. (2011). Behavioral change starts in the family: The role of family communication and implications for social marketing. Journal of Nonprofit and Public Sector Marketing, 23(4), 367-386.

Vygotsky, L. S. (1978). Mind in society. Cambridge, MA: Harvard University Press.

Wardat, M., \& Alkhateeb, O. (2016). The expressive and emotive function in the Jordanian parent-child interactions. International Journal of Linguistics (Forthcoming), 8(5), 107-125.

Zolten, K., \& Long, N. (2006). Parent/child communication. University of Arkansas for Medical Sciences Artwork by Scott Snider, Tennessee, USA. 


\section{Appendix 1: Mother Questionnaire}

Dear Respondent,

The purpose of the study is to examine the informative and referential pragmatic function of the parent-child interactions. The questionnaire asks about the effects of the mother on her children. Please do not write your names; your responses will be used only for the sake of this study. They will be top secret, and will never be used but just for this study.

Male $\square$ Female $\square$ Number of Children in the Family: Date:

Part -1-:

1. My mother has the final say in any chat.

2. My mother asks for advice when she needs it.

3. My mother helps me with my homework.

4. My mother takes care of me.

5. My mother asks me for my opinion.

Part -2-:

\begin{tabular}{|l|l|l|l|l|}
\hline never & rarely & sometimes & often & always \\
\hline & & & & \\
\hline & & & & \\
\hline & & & & \\
\hline & & & & \\
\hline & & & & \\
\hline
\end{tabular}

1. What I like about my mother:

2. What I do not like about my mother:

\section{Appendix 2: Father Questionnaire}

Dear Respondent,

The purpose of the study is to examine the informative and referential pragmatic function of the parent-child interactions. The questionnaire asks about the effects of the mother on her children. Please do not write your names; your responses will be used only for the sake of this study. They will be top secret, and will never be used but just for this study.

Male $\square$ Female $\square$ Number of Children in the Family: Date:

Part -1-:

1. My father has the final say in any chat.

2. My father asks for advice when he needs it.

3. My father helps me with my homework.

4. My father takes care of me.

5. My father asks me for my opinion.

Part -2-:

\begin{tabular}{|l|l|l|l|l|}
\hline never & rarely & sometimes & often & always \\
\hline & & & & \\
\hline & & & & \\
\hline & & & & \\
\hline & & & & \\
\hline & & & & \\
\hline
\end{tabular}

1. What I like about my father:

2. What I do not like about my father: 